Albert Blum. "The Role of Labor in the Arts."

David Goodman. "Nightriders in Grants: A New Mexico Mining Strike of the 1930s."

Miguel Casillas. "Agitation or Discrimination: A Reappraisal of the Clifton-Morensi Strike."

Richard Melzer. "Madrid: Life and Labor in a New Mexican Mining Camp during the Depression."

Raui Teilhet. "The Rodda Act and Collective Bargaining for Teachers."

George Papyack. "Recent History of Organizing Professional Public Employees."

J.J. Cardoso. "The North American Aviation Strike of 1941."

Frank Arnold. "The Organizing of Cannery Workers in the Santa Clara Valley."

John Monfross. "The Formation of the Associated Farmers of California."

Sam Kushner, Jacques Levy, Ron Taylor, "California Agriculture Labor: A Historical Perspective."

Mario T. Garcia, "Obreras: The Mexican Female Workers of El Paso, 1890-1920."

Keith Collins, "Black Los Angeles: The Maturing of the Ghetto, 1940-1950."

R. Griswold del Castillo, "The Making of a Barrio: Los Angeles, 1850-1880."

Nicholaas Steeinik. "I.W.W. and Criminal Syndicalism, 1919."

Robert Wheeler. John Amsden. Bernard Moss. Beverly Springer (panel), "Communism and Labor in Southern Europe."

Gloria Lathrop. "Working Women and Entrepreneurs in the trans-Mississippi West, circa 1890."

Alice Clement. "Agnes Nestor, Mary Anderson and the Origins of Protective Legislation for Women."

Sarah Rosner. "A Working Woman in the Needle Trades, 1915."

\title{
THE CHICAGO WOMEN'S LABOR HISTORY PROJECT
}

This project has been extending the audience for labor history in the city which New York joumalist Hutchins Hapgood sought out in 1905 to capture "the spirit of labor." Last May Chicagoans watched their class-conscious past through the project's slide show at the Lakeview Jane Addams Center, the Uptown public library, and the offices of the American Federation of State. County, and Municipal Employees local 10006. "We Shall Fight Until We Win" draws upon archives, newspapers, oral histories. and monographs to narrate the Chicago working class's fight against capitalism. The script focuses on the garment and meat packing industries. those sectors of the economy which provided the most paid jobs for Chicago's female population well into the thirties when clerical and service employment statistically begin to prevail. However. the script recognizes that women work as unpaid laborers in the home, that the world of work affects the household. Pictures of coal gathering in 1902, breadlines in 1893 and 1910, garbage scaveging in 1932. rationing during World War 11, and consumer boycotts in 1974 convey the connections between what we are told are separate spheres.

Slides present the irnnies which result from mixing feminism with unionism. We see the 1910 uprising of forty-thousand sparked by women garment workers and then view anti-cviction demonstrations nut of the Great Depression which. despite strong female leadership in Chicago. 
appealed through images of "Sacred Motherhood," the caption on a poster which came out of the garment battles. We look at the press photographing women throwing red pepper into the eyes of police horses as the Polish community defended itself during the 1921 stockyards strike. We watch headlines announcing the official breakup of Margaret Haley's Federation of Teachers which unionized the first and most numerous of white collar workers, the "school marm." We observe conditions in home sweatshops and "behind the yards." in the streets reserved for Blacks in 1919 and in offices containing the modern streamlined secretarial pool. We are reminded of the city hall janitresses' fight for "equal pay for equal work" and the Amalgamated Clothing Workers' recent solidarity with striking Farrah pants employees. We see the struggle of Chicago's Latino and Black populations in the context of earlier arrived ethnic groups.

"We Shall Fight Until We Win" projects images of people together amid police brutality. crowded tenements, and other spin-offs from "the capitalist pyramid." to name a popular late nineteenth century socialist cartoon in the collection. The slides show radicals and feminists aiding the working class. We see union meetings, day care centers. immigration classes, visiting nurses. and settlement house activities. The role of famous heroines is underplayed in favor of the experiences and actions of many people. though individual portraits flash into the story: Lucy Parsons and Mother Jones. Mary McDowell and Ellen Gates Starr. Mary Kenney and Jane Addams. Rather than celebrating women as bus drivers, telephone repairers. and toolmakers. stills of women at work underline how economic needs underpin diminished or changed sex-type labor.

The project began in May, 1975. Members came together as a Chicago Women's Liberation Union reading group to prepare for a national conference of Socialist Feminists. Instead of disbanding afterwards, the group decided to study labor history. In January, 1976 the American Issues Forum funded the slide show and a Chicago premier of "Union Maids," the documentary film Julia Reichart. James Klein. and Miles Mogulesque constructed from the interviews in Rank and File. The project sponsored discussions following the film with the authors of that book. Alice and Staughton Lynd, and the three featured Chicago women who were CIO organizers.

Only one academically trained/professional historian, this reviewer, belonged to the collective. We consulted "professional humanists" as required by American Issues, particularly William Adlemann from Labor Education. University of Illinois. Chicago Circle, Les Orear from the Almagamated Meatcutters and Butcher Workmen of North America and President of the Illinois Labor History Society. and Carolyn Ashbaugh, an independent author. Research was done at the Chicago Historical Society, the Circle Midwest Archives, the Schlesinger Library, the Newberry Library, the Illinois Labor History Society, and University of Chicago Special Collections. Other members of the project include: Barbara Drazin, Hillary Hunter. Jeri Jender, and Chris Johnson. The project demonstrated for me how individuals can pool their skills to undertake serious scholarly research and then disseminate their findings in a readily comprehensible form to the larger public.

\author{
Eileen Boris \\ Grinnell College
}

